Commentary

\title{
Personalized Medicine, Genomics and Enhancement: Monuments to Neoliberalism
}

\author{
Charles Joseph Kowalski, Adam Joel Mrdjenovich \\ Health and Behavioral Sciences IRB, Office of Research, University of Michigan, Ann Arbor, USA
}

Email address:

chuckk@umich.edu (C. J. Kowalski)

\section{To cite this article:}

Charles Joseph Kowalski, Adam Joel Mrdjenovich. Personalized Medicine, Genomics and Enhancement: Monuments to Neoliberalism. American Journal of Clinical and Experimental Medicine. Vol. 5, No. 3, 2017, pp. 75-92. doi: 10.11648/j.ajcem.20170503.14

Received: March 24, 2017; Accepted: April 6, 2017; Published: April 30, 2017

\begin{abstract}
This essay explores the meanings, possibilities, limitations, and some of the relationships between three currently much discussed - and debated - topics: personalized medicine, genomics, and enhancement. We believe, and gather in one place some of the literature supporting the view that all three are largely the product of the current dominant ideology of neoliberalism with its emphasis on individual freedom of choice, unwavering trust in the "wisdom of the market," the commodification of everything, including information and promise, and the associated scientific viewpoints it employs, reductionism and biological (especially genetic) determinism. We recognize that the success (or failure) of approaches to problems based on reductionism and/or genetic influences depends upon the problem(s) considered and the uses to which the accumulating insight will be employed. We believe that we can often do better than focusing on profit motives when determining which problems to study and which outcomes are most useful.
\end{abstract}

Keywords: Biological Determinism, Reductionism, -Omics, Medicalization, Horses for Courses

\section{Introduction}

This essay develops the thesis that certain recent developments in biology and medicine have been the all but inevitable result of the current neoliberal ideology as it seeks to "commercialize everything." It combines an expression of our viewpoint that neoliberal thinking should not guide the structures of our scientific research and health care delivery systems with a selected review of the literature supporting this thesis. We begin, in Section 2, with some definitions of, and elaborations on, neoliberalism. We focus on the effects that neoliberalism has had on higher education and science, setting the stage for subsequent applications to personalized medicine (PM, Section 3), genomics (G, Section 4) and enhancement (E, Section 5). The general features of neoliberalism described in Section II are specialized to these areas of application as we proceed. We then (Section 6) discuss some of the relationships between personalized medicine, genomics, and enhancement. We recognize that economic constraints can set priorities for research expenditures, and, following Dickenson [1] suggest that ME medicine (personalized healthcare, typified by direct-to-consumer genetic testing, personally tailored drug regimens and enhancement technologies) not supplant WE medicine (programs like public vaccination, clean water, and screening for tuberculosis; widespread and accessible publically funded healthcare) if the aim is to make the world a better (or, at least, a healthier) place in which to live. We recognize here, as well as throughout the essay, that what we aim for is a major determinant of our actions. A focus on corporate profitability may lead to a better, healthier existence for those able to afford highly personalized techniques for diagnosis, treatment and enhancement, but it is unlikely to better the lot of most, let alone to enhance health worldwide.

\section{Neoliberalism}

Definitions of neoliberalism are as numerous as there are those who have written about it. These definitions have varied over time and place and have served a number of purposes. Our take on neoliberalism is the one that has evolved since the 1980s, mainly in the United States and the United Kingdom, as typified by the policies of Ronald Reagan and Margaret 
Thatcher. Differences in definition remain, but they differ mainly in emphasis and we cite three definitions which should capture the spirit of the movement. The first provides a snapshot of what neoliberalism looks like today; the second points to its philosophical underpinnings; and the third looks at the extent to which neoliberalism has invaded social spheres beyond the economic.

We begin with Dickenson's [1, p. 19] characterization of neoliberalism as including "rolling back the state, by limiting regulatory legislation and cutting public spending, while increasing the involvement of private corporations in key governmental functions. Viewing the market as the only necessary form of discipline in any economy, monopoly contracts are allowed and necessary services outsourced. The concept of public good is downplayed if not completely ignored."

Harvey [2] considers both what neoliberalism "looks like" and the motivation behind its development, defining neoliberalism as, "a theory of political economic practices that proposes that human well-being can best be advanced by liberating individual entrepreneurial freedoms and skills within an institutional framework characterized by strong private property rights, free markets, and free trade." (p. 2) and "[n] eoliberalism has meant, in short, the financialization of everything" (p. 33).

Brown [3, p. 9-10] includes the penetration of neoliberal tenants, stressing that neoliberalism is more than just the spread of market values, that it needs to be understood as more than a set of economic policies, an ideology, or a resetting of the relation between state and economy. Instead, it is to be seen as "a normative order of reason developed over three decades into a widely and deeply disseminated governing rationality, neoliberalism transmogrifies every human domain and endeavor, along with humans themselves, according to a specific image of the economic. All conduct is economic conduct; all spheres of existence are framed and measured by economic terms and metrics, even when those spheres are not directly monetized."

One feature of neoliberal thinking is that no one individual, or group of individuals (viz., the government) is capable of understanding enough about any society or economy so as to be able to select the "best" of the possible models to follow. Accordingly, the only solution to achieving the best economy is to allow all possible systems to be tried and to allow the best to emerge through competition. A corollary to this elevation of the market to the exclusive arbiter of "the truth" has been the development of ways to deploy ignorance as a political tool. Mirowski [4, p. 226] referred to this as Agnotology, the focused study of the intentional manufacture of doubt and uncertainty in the general populace for specific political motives, and noted that the earliest instances of agnotology were found in the natural sciences, on the political controversies over the cancer consequences of tobacco smoke, Star Wars antimissile systems, the theory of evolution, the efficacy of pharmaceuticals, and the causes and consequences of global warming [5, 6].

Brown [3, p. 67] phrases this in terms of Foucault's "veridiction" (truths that are established, rather than foundational, but nevertheless govern): with neoliberalism, the market becomes the, rather than $a$ site of veridiction and becomes so for every arena and type of human activity. The market is itself true and also represents the true form of all activity.

Mirowski [4] gives an insightful summary of the history of neoliberalism, its effects on the economic profession, and a revealing expose of how neoliberalism not only survived the financial crisis of 2008-09, but actually emerged stronger than before. When neoliberal policies caused economic problems, the solution to those problems was, invariably, "more neoliberalism."

We do not pursue neoliberalism and all of its far-flung ramifications further in this paper. Rather, we focus our attention on activities that have to do with knowledge production (and commodification) and the application of such knowledge to providing health care.

Of direct relevance to our discussion is the impact that neoliberalism has had on our universities and the scientific community at large. The effects that neoliberal ideology has had on higher education were described by Ginsberg [7], Giroux [8], and Olssen and Peters [9]. Ginsberg [7] argued that neoliberalism has transformed the University from an institution devoted to teaching and research into pseudo-corporations focusing on the bottom line. Students have become customers, interested more in training for positions in the neoliberal workplace than in more traditional curricula aimed at critical thinking and readiness to assume meaningful positions in a society that values more than individual freedoms; and professorial ranks have been diminished (to the point that they are outnumbered by administrators bent on economic development) by adding large numbers of part-time, less costly, and easily expendable teachers or, even, eliminated entirely by having students teach themselves on-line (with no reduction in tuition, but easily-accessible student loan programs). Giroux [8, p.13] remarked on the effects of both higher education, and on public education more generally: “... the search for high-end profits has descended upon the educational sector with a vengeance, as private bankers, hedge fund elites, and an assortment of billionaires are investing in for-profit and charter schools while advocating policies that disinvest in public education. At the same time, the biotech, pharmaceutical, and defense industries and a range of other corporations are investing in universities to rake in profits while influencing everything from how such institutions are governed and define their mission to what they teach and how they treat faculty members and students."

Mirowski [4, p. 6] gives the definitive account of how neoliberalism has transmogrified the University and science quite generally. In particular, he points to the commodification of information: "Since 1980, we have lived through a period of profound transformation in the social practices, institutions, rules, and formats of the generation and conveyance of information, one that has slowly but inexorably transformed the very meaning of knowledge and the place it occupies in the 
modern polity." Thus is information rendered amenable to ownership and control.

Neoliberals had won: Science no longer qualified as a public good. Instead, science became one of the drivers of economic growth. The commercialization of science is the apotheosis of the neoliberal program.

Fisher [10] focused on the clinical trial industry. In particular, she describes the impact neoliberalism has had on the pharmaceutical clinical trials industry. This is a form of "medical neoliberalism," characterized by a commodification of health that transforms individuals from patients into consumers. She recognizes that medical neoliberalism is a reductionist tactic, fragmenting the body by isolating specific problem areas, and resulting in products designed to maintain, cure, or enhance them. She also recognizes that among the dangers of this fragmentation are new perceptions of disability, and the rise of transhumanist models of medicine in which the focus is no longer on health but on enhancement.

Esposito and Perez [11] extend discussions of neoliberalism in the context of medicine to the mental health field. They describe a market reality that situates mental health as a commodity, prompts individuals to adopt the role of consumer, and implies that the acquisition of products and services corresponds to the pursuit of a fulfilling life. In this way, mental health and well-being largely become functions of consumerism, "Because neoliberalism has increasingly shaped... mental health care... according to the logic of the market... solutions to mental health problems are increasingly... defined on the basis of commercial appeal" [11, p. 6]. Esposito and Perez [11] conclude that offering consumption (e.g., of psychotropic medications) as a solution for people who might be depressed or anxious reinforces the medicalization of human life. It is interesting to note that the "consumer" movement - which emerged in the mental health arena during the $1980 \mathrm{~s}$ as a form of activism and self-advocacy on the part of individuals facing mental health issues - equated the right to make choices as a consumer in the mental health system with empowerment [12]. As Everett [13, p. 145] observed, the consumer designation “... attempts to empower patients and clients by equating them with customers - a term which, in the sphere of the marketplace, denotes people who are respected because they demand satisfaction or else they will take their business elsewhere". However, the same designation is problematic according to Everett [13] because it infers that mental health concerns are best addressed through marketplace solutions.

Lewontin et al [14] point to a clear link between the rise of neoliberalism in the 1980s (Reagan and Thatcher) and the adoption of a conservative ideology based on individualism, with its emphasis on the priority of the individual over the collective. This priority is seen as having both a moral aspect, in which the rights of individuals have absolute priority over the rights of society, and an ontological aspect, where society is viewed as nothing more than the sum of the individuals that make it up. This view encapsulates two philosophical stances, namely reductionism and biological determinism.

Reductionists try to explain the properties of complex wholes in terms of the units of which those wholes are composed. Thus, to understand society, one studies the individuals comprising it. The biotech model of commodification has tended to favor reductionist approaches in biology so as to produce discrete objects of ownership.

Biological determinism is also a reductionist idea: To understand human beings, study the units that determine them, as in, "human lives and actions are inevitable consequences of the biochemical properties of the cells that make up the individual; and these characteristics are in turn uniquely determined by the constituents of the genes possessed by each individual." "Human nature is fixed by our genes." [14, p. 6]. Perhaps the best exemplar of both reductionism and genetic determinism is sociobiology, which can be described as a reductionist, biological determinist explanation of human existence. In particular, such human characteristics as competitiveness are said to be determined quite naturally, as a result of gene action. Nelkin [15, p. 181] noted that when E. O. Wilson's Sociobiology was published in 1975, Business Week ran a series of articles on the "Genetic Defense of the Free Market" (p. 235). The origins of competitive self-interest were located in the human gene pool. Midgley [16, p. 3-4] showed how this followed directly from reductionism and genetic determinism. "[T]wo distinct kinds of reduction: the social atomism, which splits human society into separate, isolated individuals; and the physicalist reduction, which splits each individual into the units of his own body ... their common reductive quality makes people see them both as scientific. Taken together, they mean that all human action is unavoidably selfish." The extent to which such thinking has been taken is nicely illustrated by the titles of some of the chapters in Ridley [17]: Genome: The autobiography of a species in 23 chapters. One might conclude from these that the genes for such characteristics as intelligence, instinct, conflict, self-interest, disease, stress, personality, memory, and the pathways to a number of diseases, including their preventions and cures, can in fact be located on certain of the human chromosomes.

Another, more direct, way to see the relationship between neoliberalism and reductionism was indicated by Olssen and Peters [9] who said that Frederick Hayek (who, along with such names as Milton Friedman and Ayn Rand are widely recognized as important neoliberal theorists) emphasized that knowledge of some parts of a structure permit the formation of correct understanding about the behavior of the structure as a whole.

Thus neoliberalism is both explained by, and helps to explain, reductionism. Sunder Rajan [18, p. 142] described the coproduction of neoliberalism and genetic determinism as resulting in "biocapital": "Biocapital is the implosion of an emergent economic regime with an emergent epistemic one...biotechnology and subsequent genomics 'revolutions' are techno-capitalist assemblages that allow analyses, and create types of knowledge, that reconfigure definitions, understandings, even the grammar of 'life itself." This was further elaborated upon by Rose [19, p. 7]: "Life itself has been made amenable to these new economic relations, as 
vitality is decomposed into a series of distinct and discrete objects - that can be isolated, delimited, stored, accumulated, mobilized, and exchanged, according to a discrete value, traded across time, space, species, contexts, enterprises - in the service of many distinct objectives ... biopolitics has become inextricably intertwined with bioeconomics."

\section{Personalized Medicine}

Following Chadwick [20], we begin this section with the old aphorism about when philosophers are asked to give a perspective on a topic, they begin by asking what it means, and then make no further progress. When considering the topic of personalized medicine (PM), however, any hope of even being able to speak of further progress, or the uses to which PM may be put, hinges upon which of several, quite different definitions are adopted from among those available. Many of the definitions "out there" essentially equate PM to basing the treatment of an individual on genetic/genomic information. For example, the Hastings Center Report [21, p. 14], when introducing a series of essays on the subject, defined PM as the "customization of medical treatment to an individual's genetic profile." A similar emphasis on genetics was taken by the Personalized Medicine Coalition (PMC); while acknowledging that medicine has aspired to be personal for millennia, they marked the real drive toward PM as occurring in 2003 with the complete sequencing of the human genome [22]. Their entire case in favor of PM proceeds for over sixty pages without a mention of extra-genetic sources of information. The singularly powerful voices of Margaret Hamburg (then Commissioner of the Food and Drug Administration) and Francis Collins (Director of the National Institutes of Health) have joined forces in leaving no doubt that the path to $\mathrm{PM}$ was constructed using exclusively building bricks labelled A, C, G and T, the chemical base pairs that make up human DNA [23]. This is not to say that Collins and Hamburg are avowed neoliberals. Indeed, we do not claim to have personal knowledge of the motivations of such luminaries as Hamburg, Collins, Gilbert, Watson and Crick (cited below) in their enthusiastic adoption of what can only be recognized as a reductionist/genetic deterministic paradigm. We claim only that this stance is perfectly consistent with neoliberal tenants and, once having declared allegiance to this creed, promising enhanced versions of the expected results is one path to secure funding.

Much current usage seems to equate PM and genetic/genomic information, but we feel the distinction between the two to be important. It may seem to some that this is quibbling at terminology, but the distinction involves much more than semantics. PM has been around for millennia. Dickenson [1, p. 9] quotes Hippocrates: "It is far more important to know what person the disease has, than to know what disease the person has", and, in context, when an individual presents for treatment, calls upon the physician to select the treatment that promises to work best for this individual. This approach is widely accepted, whether or not the treatment plan incorporates any genetic/genomic information. To equate PM and genetics/genomics is to accept genetic determinism - it's all in the genes - which is demonstrably false and contributes more to problem formulation than solution. Genetic/genomic information may, in certain contexts, contribute to PM, but whether or not it can depends on the details of the situation. We recognize genetic/genomic information as a possible contributor to PM, but it is just one of many, and its relevance and value should be assessed prior to incorporation.

We suggest that these gene-centric definitions are better referred to as genomic medicine, viz., the use of information from genomes and their derivatives (RNA, proteins, and metabolites) to guide medical decision making, and to recognize genomic medicine as a component of PM. Thus, according to Ginsburg and Willard [7, p. 278], "Personalized medicine is a broad and rapidly advancing field of health care that is informed by each person's unique clinical, genetic, genomic, and environmental information." This allows that extra-genetic information, e.g., clinical/environmental, will inform personalization of care. Indeed, we suggest that there may be other sources of information, not usually categorized as clinical, environmental, or genetic, e.g., patient preferences [24], that should be taken into account in tailoring treatment. Accordingly, we follow Gamma [25], by adopting a broad definition of personalized medicine as the attempt to improve health by any means that makes treatments more individual-specific, more targeted, and more effective, while at the same time minimizing adverse side-effects. Thus PM aims at more accurate diagnosis, better prediction of individual disease risks, and individually tailored preventive interventions to decrease or eliminate the risk of disease. Here the use of the phrase by any means does not point to any particular, privileged path to health improvement; depending on context, one or another of the possible sources of information may prove decisive, but it would be a mistake to tie personalization strictly to genetics: There is a lot more to us than that contained in our genes [22]. Surely genomics is a possible contributor to (at least certain aspects of) PM, but it is only one of several, and its relevance and value in a particular application should be assured prior to incorporation.

Sunder Rajan [18, p. 153] pointed to one uncontested difference between pharmacogenomics and PM. He warned, "Do not conflate pharmacogenomics and personalized medicine: There are important differences between genetic effects on diseases and on drug action." He also noted the influence of the market on PM: "Personalized medicine refers not just to new types of therapeutics but to a new ensemble of techniques, practices, and institutional structures of medicine, one that is determined to a significant degree by the market" (p. 135).

Thus, in this essay, we wish to honor the long well-established aspirational goal of treating the individual patient in the way determined best for that individual, but will argue that genomics has but a limited role to play in this regard. We follow Gamma [25, p. 508]: "Personalized medicine is too good an idea to be left to the uncontrollable dynamics of a research marketplace ruled by the rhetoric of hype and the logic of profit." 


\section{Genomics}

Nobel laureate Walter Gilbert [26, p. 94], writing at the inception of the Human Genome Project (HGP), thought that the genome was the holy grail of genetics, and the key to understanding what makes us human:

"The possession of a genetic map and the DNA sequence of a human being will transform medicine...we will be able to identify whole sets of genes that influence general aspects of how the body grows or how the body fails to function. We will find sets of genes for such conditions as heart disease, susceptibility to cancer, or high blood pressure. Along with ... such mental conditions as schizophrenia, manic-depressive illness, and susceptibility to Alzheimer's disease. A whole variety of human susceptibilities will be recognized as having genetic origins."

Observations such as these, made by a number of influential biomedical researchers [27, p. 1; 15, pp. 6-9] made the HGP the next obvious step on the road to the holy grail. As explained by Keller [28, p. 21], prominent metaphorical signposts along the way paved much of the promissory currency enjoyed by the project: "When Watson and Crick [1953] introduced the information metaphor (DNA carries the genetic information, or program, and genes produce their effects by providing the instructions for protein synthesis: DNA makes RNA, RNA makes proteins, and proteins make us), they set the stage for the HGP. If all development is merely the unfolding of preexisting instructions encoded in the nucleotide sequences of DNA - it makes perfect sense to set the identification of these sequences as the primary and, indeed ultimate, goal of biology."

But a funny thing happened on the way to the holy grail.

Keller [28, p. 22]

The promissory statements used to promote the HGP proved at best premature. Reality turned out to be more complicated than could be read from a genetic blueprint. Panofsky [29, p. 168] thought, "Postgenomic scientists are embarrassed by the 'Holy Grail' and 'Book of Life' talk used to sell the HGP," and that, "Molecular genetics has been a major disappointment, if not an outright failure, in behavior genetics" (p. 157). Keller [30] thought that one of the biggest surprises of the HGP was the relatively small number of genes to be found: $20,000-30,000$, not very different from the number found in C. Elegans, the lowly earthworm. This caused a shift in metaphor for extragenic DNA matter from 'junk' to 'dark matter of the genome.' This also opened the door for the so-called ENCODE Project, discussed below. Keller [30, p. 10] also argued that HGP "turned our understanding of the basic role of the genome on its head, transforming it from an executive suite of directorial instructions to an exquisitely sensitive and reactive system that enables cells to regulate gene expression in response to their immediate environment." This in turn opened the door to an entire field, epigenetics, which was defined by Stevens and Richardson [31, p. 4] as the study of mechanisms that regulate gene expression in response to environmental signals. Thus, the environment regained its rightful place in the study of human nature. Even if it were possible to know the exact sequence of A, C, G and Ts comprising the DNA of a "normal" human being, this could tell at most a limited part of the story of that person. As summarized by Keller [32, p. 7] "the development of phenotypic traits is guided not so much by the actual sequence of nucleotides as it is by patterns of gene expression that are themselves products of an immensely complex web of interactions between environmental stimuli (both internal and external to the cell) and the structure, conformation, and nucleotide sequence of the DNA molecule."

There were also some economic lessons to be learned. Graeber [33, p. 133] thought that the most significant thing to be learned from the HGP was, "the hype and political investment surrounding such projects demonstrate the degree to which even basic research now seems to be driven by political, administrative, and marketing imperatives." Keller [30] considered that the HGP initiated several turning points in the history of genetics, the most important being the role it played in the rise of "biocapitalism" and the commercialization of genetics.

We cannot help but note that a number of scholars (some pro-market and some anti-market) had questioned the wisdom and/or feasibility of the HGP long before the paucity (at least as compared to what was promised by its advocates) of its results became known. Kevles and Hood [34, p. 300ff] pointed to some of these in their summary (Reflections) chapter, noting that many were concerned that this 'Big Science' approach to biology would limit the funds available to individual or smaller groups of researchers who actually had testable hypotheses in mind prior to data collection. The fear was that by limiting attention to genomic sequencing we would be creating armies of technicians skilled at nothing but DNA sequencing and data entry. Other representative naysayers included Lewontin [35], Tauber and Sankar [36] and Strohman [37] who voiced more basic, theoretical concerns. Despite these warnings the HGP proceeded unabated. Pro-market forces prevailed. Virtually none of its promises were fulfilled; and apparently, as we discuss below, little was learned about the perils of investing in massive data collection projects without a careful consideration of the value placed on the informational content of the data to be obtained.

So, given the results of the HGP, limited though they may be, what do we do next? Two main strategies emerge: First is to recognize the HGP as a tool; the second is to double-down on the HGP, repeating the approach on targets other than the genome. These are discussed in turn in the subsections following.

\subsection{The HGP as a Tool}

Even Gilbert eventually recognized that the HGP was an application of scientific technology to produce a well-defined end - the information content of the human genome. He came to admit that the HGP itself was not expected to answer questions concerning the precise functioning of all human genes and their interactions: Rather, it developed the human sequence as a research tool. Hood [38, p. 138] also thought 
that the map of the human genome would be viewed as a powerful tool "that will significantly enrich the infrastructures of biology and medicine." Kevles and Hood [34, p. 309], when reflecting on the HGP and the resulting "orgy of information," recalled the words of Francis Collins who thought these data "would drive the research enterprise for at least the next 100 years." These more sober assessments of what the HGP could accomplish stand in contrast to those proffered to secure its funding. A tool and a source of information are a far cry from "learning the language in which God created life," the "blueprint for humanity," or an "accomplishment surpassing putting a man on the moon." That there are discrepancies between what was promised and what was actually delivered is not surprising. Consumers everywhere know the old adage of buyer beware, and the nature of the promises made when playing the genomics game is, by its very nature, speculative. One would expect that those applying for funds to do the HGP would "put their best foot forward." Fortun [39, 40] gives a thoughtful discussion of these matters, respectively for the HGP and for genomics companies generally, noting that the language in which genomics in the 1990s "was - as it had to be, as it must continue to be - written about, gossiped about, thought of, and evaluated: in a language of promising" [40, p. 9] [emphasis in the original]. The tie to neoliberalism was also not any secret. He quoted a Johnson and Johnson executive testifying to Congress: "If we want the U.S. to maintain its position as a dominant force in the pharmaceutical industry in the world, I cannot imagine letting this opportunity pass us by ... The group that first gains access to the information from mapping and sequencing the human genome will be in a position to dominate the pharmaceutical and biotech industry for decades to come" [40, p. 37]. Rose [41, p. 79] also noted the relationship between promises and the market: "Contemporary bioscience and biotechnology, no doubt following a pattern familiar from other technologies, thrives on such expectations of epochal changes just around the corner; such claims generate publicity, inflate share prices, mobilize funding agencies, enhance careers and, no doubt, generate a sense of excitement and mission for those working in the field."

In any case, one of the first uses of the results of the HGP was the Genome Wide Association Study (GWAS). GWASs examine many common genetic variants in different individuals to see if any variant is associated with a trait. Typically, GWASs focus on associations between single nucleotide polymorphisms (SNPs) and a disease: The DNA of two groups is compared, people with the disease (cases) and people without the disease (controls). If one or more variants are more or less frequent in cases than controls, the corresponding SNPs are said to be associated with the disease.

A major, related initiative, the International HapMap Project was launched in 2002 with the expressed intention of developing a tool, i.e., with the aim of "providing a public resource to accelerate genetic research" [42, p. 851]. The project was done in two phases: In the first, some one million SNPs were characterized, two more million were identified in phase 2. When announcing the results if phase 2, Frazer et al
[42] claimed that the results from phase 1 were already playing "a central role in the development of methods for the design and analysis of Genome Wide Association Studies. These advances, alongside the release of commercial platforms for performing economically viable genome-wide genotyping, have led to a new phase in human medical genetics."

Some have viewed the fact that, in GWAS, one need not specify in advance "candidate genes" as an advantage. This type of research is often called "hypothesis free" in that you have no hypothesis about what, where, or how gene sequences may be implicated [43, p. 433]. Crunch the data and find out. Well, that's exactly what happened: To date, thousands of individuals have participated in GWASs studying hundreds of diseases and traits, and thousands of SNP associations have been found. Visscher et al [44] summarized what had been learned by GWASs after five years. See also Stranger et al [45]. Perhaps the most striking, and consistent, finding has been called the "missing heritability problem." Stevens and Richardson [31] described this as follows: Despite the many locations on the genome responsible for influencing particular traits or diseases, adding up all the contributions of these sites accounts for only a small to moderate percentage of the total variability exhibited by these traits/diseases.

A revealing example of this is a particularly well-known human trait, height. A study done in 2010 [46] found some 180 locations on the genome to be associated with height, but even when the contributions of all sites was taken into account, these only accounted for $13 \%$ of the overall variability in human height. This stands in contrast to the results of twin studies accounting for some $80-90 \%$ of the variability.

Given these outcomes, questions were raised about the basic design of GWASs. Steele [47, p. 181] thought that GWAS studies concentrated on the wrong things: "Particularly suspect are those genome wide association studies using single nucleotide polymorphisms (SNPs), where the aim is to link a disease predisposition, or some other qualitative characteristic, with a particular genetic locus tagged with a SNP, a process called linkage disequilibrium (LD) analysis." His argument is quite technical, but it comes down to the fact that SNP-LD studies view genes as "beads on a string," while their distribution in the mammalian genome is more like "peas in a pod." In any case, Steele [47, p. 184], thought, "There seem to be deep and fatal flaws in all genome-wide association studies involving SNPs."

Others, while not questioning the design, thought that the missing heritability was to be found in environmental variables. The thought was that since GWAS was able, e.g., to account for only $10-30 \%$ of the variability for cancers and cardiovascular problems, non-genetic factors (environmental factors) may be the major causes of chronic diseases, and EWASs, where Environment takes the place of Genome, were commissioned. For example, Patel et al [48] reported an EWAS on type 2 diabetes mellitus. They found associations between environmental exposures and type 2 diabetes with effect sizes "comparable to the highest odds ratios seen in GWAS" (p. 8). The two approaches (GWAS and EWAS) were 
soon combined to produce Gene-Environment-Wide Interaction Studies (GEWIS); see Khoury and Wacholder [49] for a review. GEWIS represents a major increase of the dimensionality of the problem with the added complexity of studying interaction effects. They have so far provided us with more evidence about how much remains to be learned about the etiology of complex diseases. Progress may be expected only if major improvements in our data analytic abilities are forthcoming. As stated by Khoury and Wacholder [49, p. 229], "We need some analytic help to make the GWAS efforts more productive by addressing biologic, clinical, and public health questions, not only academic abstractions!"

We believe that the problems surrounding the use of the HGP results as a tool are best explained by the "tools to theories" idea developed by Gigerenzer [50]: ways of organizing data that begin as technical tools have a habit of becoming the very premises of the theories that seek to explain that organization [50, p. 435]. This was also emphasized by Lewontin [51]: "The problems on which geneticists work have become those that can be answered from DNA sequences ( $p$. 128)... "A single easily acquired technique changed and pauperized, temporarily it is to be hoped, an entire field of study" (p. 129). "Scientists pursue precisely those problems that yield to their methods" (p. 72-3) ... "Science as we practice it solves those problems for which its methods and concepts are adequate, and successful scientists soon learn to pose only those problems that are likely to be solved" (p. 73). We believe this trend needs to be reversed. Rather than finding jobs to fit the tool, we should identify those jobs most in need of doing, and then select the appropriate tool. If the HGP sequence turns out to be that tool in a particular case, so be it. But tool selection should follow from job specifications, not dictate them. We argue for a "horses for courses" approach [52]. Horses for courses is another way of saying "pick the right tool for the job." A hammer may be best for driving a nail, but there are better ways to fasten a screw. RCTs may be best to establish efficacy, but observational studies are a better way to assess long-term safety concerns [53]. The market may be the best way to decide certain questions, but it cannot be best for all of the questions that need be answered in designing and achieving effective and equitable health care structures. Arrow was right on target here.... [54].

\subsection{Doubling Down}

The strategy adopted here is reminiscent of the neoliberal reaction to the financial crisis of 2008-09: The solution to the problem was more neoliberalism. Here the "big data" approach was not seen as problematic; it was the target that needed refinement/expansion. It seems as though collecting more and more data validates its collection in the first place reflexivity in action. Thus, genomics led to the development of several xxxxomics, e.g.,

Proteomics

Metabolomics

Transcriptomics

Exposomics (microbiomics)

Toxicogenomics
Lewontin [51] indicated that some molecular biologists believe that the genome was not really the right target and that we should have been studying the "proteome," the complete set of all the proteins manufactured by an organism. Apparently, these alternatives became more attractive given the limitations of the HGP. Even the PMC [22] thought that thought moving beyond the genome was going to be required: On to the proteome, the metabolone, and the epigenome ....

It was, of course, recognized that, like the HGP before them, these efforts would have to attract funding. Batteries of new promises were not readily available (having already promised the moon and the stars for the HGP), however, and so there was a doubling down on the old ones. Nerlich and Hellsten [55] studied the shifts and changes in the metaphors used to describe the human genome project between 2000 and 2003, with the year 2001 (The year of the publication of the initial sequencing of the human genome) as the trigger. They found that while Venter (Craig Venter is perhaps best known for leading Celera Genomics in a race with the HGP to sequence the human genome) had changed his tune, now proclaiming that the human genome is NOT the book of life, the blueprint of humanity, the language of God, the parts list of humanity, he provided no new alternatives, and many of the old metaphors survived and were simply adopted by the proteomics movement. The same could be said of metabalomics, transcriptomics, and the other-omics listed above. This is despite the fact that some of these projects were to be much bigger than the HGP. Consider, e.g., microbiomics.

Nerlich and Hellsten [55] noted that the finding that the HGP had promised more than it delivered, led to a "new frontier," conceived as a "second human genome project" was launched. It was called The Human Microbiome Project. When announcing the HMP, NIH defined the microbiome as the full collection of microbes (bacteria, fungi, viruses, etc.) that naturally exist within the human body. Initiatives in this area would focus on developing a deeper understanding of these communities of microbes in order to determine how they affect human health. For a good description of the HMP, see [56]. There is no question this is BIG science; the project involves some 200 scientists at 80 institutions around the world "who aim to sequence, categorize and catalog the genetic material of the microbiological organisms, largely bacteria, that live in, on, and alongside their human hosts" (p. 209). They began by studying specimens obtained from 242 adults deemed to be "healthy," and soon found out how BIG this project really was, something one might have thought would have been assessed before beginning the project proper. As pointed out be Schneider and Winslow [56, p. 209], "The 'healthy' adult human adult houses hundreds of trillions of bacteria, 100 trillion in the digestive tract alone."... "The HMP now estimates that the commensal bacteria that reside on and in that individual's body incorporate a total of some 3 million different genes, suggesting a ratio of microbial to human genes of at least 130 to 1." [This assumes, as the HGP has suggested, that there are approximately 23,000 different genes, on average, in an individual human].

Once again, the HMP found that things were considerably 
more complicated than they seemed going in. Blaser et al [57, p. 213] noted, "A very surprising finding has been that disruption of the homeostasis between the microbiota and the host ... has a more important role than host genetics in the development of a range of diseases, such as inflammatory bowel disease, obesity, and type 2 diabetes."

This focus on the microbiome was approached from a different angle by Shostak and Moinester [58]; they called the field exposomics to honor its emphasis on exposures to environmental challenges. They began with the thought that one of the paradoxes of the HGP was that it highlighted the role of the environment as "a major piece of the puzzle" of human health and illness. They saw focusing more on gene-environment interaction as a necessary corrective to the HGP's genocentric view of health/illness, and that genocentrism was what led to the unrealistic expectations and disappointment in the HGP. Thus they considered exposomics, a field studying "the whole environment we have inside our bodies." It is a part of "exposure science" [59] which includes the study of internal exposures (e.g., processes internal to the body such as metabolism, gut microflora, inflammation, etc.), specific external exposures (e.g., radiation, infectious agents, diet, etc.) and general external exposures (e.g., education, social capital, stress, etc.).

This is clearly tied to personalized medicine in that by focusing on the internal environment - which is unique to each individual - individual assessments are assured. If the internal environment can be readily assessed, e.g., by a simple blood draw, this would have implications for addressing pressing issues of health care disparities in the US and globally. Venture capital has been attracted: Elizabeth Holmes' theranos com and Dr. Eugene Chan's DNA Medicine Institute (both written up in Time magazine; Holmes was one of the 100 most influential people in 2015).

We should recognize that exposomics is still basically a reductionist approach and, as such, may divert attention away from social structures and practices (particularly in the context of neoliberal favoring of individualistic explanations of health, discounting social determinants of health disparities), recasting even the most socially determined exposures as individual traits. The neighborhood in which you live may be an important health determining factor (many health disparity researchers employ the slogan, "your zip code is more important than your genetic code"), and may prove to resist reducibility when developing strategies for improvement. The reason for this change in focus may be tied to financialization: Exposomics intentionally embraced the molecular (reductionist) approach. Traditional toxicologists were being "left behind." In an effort to maintain scientific respectability and obtain funding for their work, exposure science turned to study of the molecular effects of exposures,

Let us consider yet another strategy for dealing with the paucity of HGP outcomes. According to Stevens and Richardson [31], problems with the HGP also led to the rise of epigenetics, the study of mechanisms that regulate gene expression in response to environmental signals, and to projects such as ENCODE (Encyclopedia of DNA Elements).
They thought that the root of the ENCODE project was continued financial support of genomics, hoping to explain what the HGP could not, yet still staying within the confines of the genome. When the project ended in 2012 - it began in 2003, just as the HGP was ending - the ENCODE Consortium claimed that $80 \%$ of human DNA had some function, challenging the thinking about "junk" DNA, and setting the stage for a continuance of the funding of genomic research. The $80 \%$ figure was questioned by many, and critics questioned the promises being made by genome sequencing boosters arguing that their optimism just exposed their allegiance to genetic reductionism and bald biological determinism. "Rather than settling debates, ENCODE has muddied the waters; rather than answering questions, it has raised new ones" [31, p. 6).

Parrington [59] is a good general reference for epigenetics, "junk DNA," and the ENCODE project. He described ENCODE as the culmination of almost a decade's worth of research involving 442 scientists from 32 institutions and costing \$288 million; "Big science at its best." He gives a balanced discussion the pros and cons of the project on p. 4; we concentrate here on one particular set of concerns. He quotes from Graur et al [60]: "According to the article, the claims of ENCODE were 'absurd,' its statistics 'horrible,' and it was the work of people who know nothing about evolutionary biology ... this is not the work of scientists. This is the work of a group of badly trained technicians" (p. 4). Parrington also commented on a slide that Grauer showed near the end of one his presentations with a photograph of dollar bills taped together in the shape of a toilet paper role, representing his view of what ENCODE had achieved with the \$288 million spent on the project (p. 93). He also mentioned an interview with Grauer that revealed his attitude towards funding 'big science' at the expense of funding traditional "small science" projects: "If you pour $\$ 288$ million into one project, you do not fund 500 other projects. You kill the careers of young scientists. They are reduced to becoming technicians" (p. 95). Parrington [53] did present some of the reactions to Grauer's claims, and noted that the cost of a single military fighter jet was some $\$ 350$ million. The point to be made here is that, should you believe funds are scarce, albeit from an arguable urgency to bolster the defense, choices will have to be made within science, and we might want to temper the current tendency to funnel all of the money into "big science" projects.

All of the examples considered above, including the HGP itself, are examples of big data/big science projects. We have pointed to a number of the failed promises of these projects but, despite the limitations, many of the participants in these projects are convinced that the general approach was not at fault. Thus, E. D. Green, J. D. Watson, and F. S. Collins [61], when assessing the impact of the HGP, which each of the three, at one time or another directed, wrote in the "Human Genome Project: Twenty-five years of big biology," Nature News and Comments 30 September 2015, that a major legacy of the HGP is a new way of doing science.

Hood and Rowen [62] also recognized that the HGP was a "big science" project that inspired subsequent large-scale data 
acquisition initiatives such as the International HapMap Project, 1000 Genomes, and the Cancer Genome Atlas. They noted that one aspect that attracted governmental support was its potential for economic benefits; for an initial investment of approximately $\$ 3.5$ billion, the return, according to Tripp and Greuber [63], has been about $\$ 800$ billion. They suggest similar significant rates of return will be possible for these other big science projects. They do admit that, "Big science and smaller-scope individual-investigator-oriented science are powerfully complementary," but they seem to be writing more about scenarios that are theoretically possible, not to slow the rise of big science in the immediate future. We consider one such project: the Human Cancer Genome Atlas Project. This was started in 2006 as a US \$100-million pilot, and is now the biggest component of the International Cancer Genome Consortium, a collaboration of scientists from 16 nations that has discovered nearly 10 million cancer-related mutations [63]. This project adopted much of the hype that accompanied the HGP, from this will "completely change how we view cancer," to it will point you to the "Achilles heel of tumors." However, writing before the initiation of the Cancer Genome Atlas Project, Miklos [64] noted that it was a BIG project (the equivalent of 12,500 HGPs), and he pointed to what he considered to be a fatal flaw. The aim of the project is to catalog all somatic mutations from primary tumors as the basis for designer drugs to cure these cancers. However, it is not the primary tumor, but the metastatic spread of a small population of deadly cells that kills in cancer. The actual tumor is relatively unimportant, and many are cured by surgery or local radiation. Cancer research has consumed hundreds of billions of dollars to date, and yet the main killers - breast, prostate, lung and colorectal cancer - are essentially as deadly as ever. Also see Leaf [65].

Maybe, someday, someone will find something of value in one or another of these data sets. They are available for study, and it might be an idea to pause and see what of value, if anything, can be extracted from them. There are reasons to hold out some hope for this. Brown and Botstein [66, p. 36], for example, pointed out, “... this technology [microarrays] is not simply about getting data faster. Data sets produced in this way have emergent properties ... when the body of expression data is large enough, and only then, the patterns and systematic features become apparent and we begin to build an integrated picture of the whole system." On the other hand, Sydney Brenner, a molecular biologist with a Nobel Prize in his pocket, has argued that 'this 'omic' science has corrupted us. It has created the idea that if you just collect a lot of data, it will all work out" [quoted in 59, p. 202]. Time will tell how this will all turn out. For now, we are content to indicate the connections of these big data projects to neoliberalism. Some were made explicit by Sunder Rajan [18] -- He emphasized the coemergence of new forms of life science with market regimes for the conduct of such science: "one can understand emergent biotechnologies such as genomics only by simultaneously analyzing the market frameworks within which they emerge." (p. 33) ... "New epistemic and technological assemblages can only be understood through an analysis of the market frameworks within which they are emergent." (p. 280) ...
"Biotechnology represents a new face, and a new phase, of capitalism" (p. 277). "Genomics allows the metaphor of life-as-information to become material reality that can be commodified ...one does not have to conceive of life-as-information: one can now represent life in informational terms that can be packaged, turned into a commodity, and sold as a database" (p. 16).

\section{Enhancement}

We begin this section with a definition of enhancement, and then we offer some context using the etiology and treatment of mental disorders as an illustration of some of the issues. According to Buchanan [67, p. 23], enhancement is "a deliberate intervention, applying biomedical science, which aims to improve an existing capacity that most or all human beings typically have, or to create a new capacity, by acting directly on the body or brain." Buchanan's reference to the brain in this definition is noteworthy. Although many years have passed since the mid-twentieth century when psychotropic drugs became the primary treatment for mental disorders1, the notion that chemical imbalances in the brain provide the "putative basis for mental disorders" is a comparatively recent phenomenon [68; see 70: p. 301]. The chemical imbalance model is significant because it could be interpreted to mean that there is an "ideal" brain chemistry against which individuals can be evaluated. Further, it may serve to "support the neoliberal values of competitiveness and consumerism... by encouraging people to always be dissatisfied and to want more" [70, p. 302]. Hamilton [71, p. 87] called this the "permanent state of unfulfilled desire". Moncrieff [70] put forward that people are encouraged to rectify their brain chemistry through consumption (e.g., of psychotropic medications). As with material consumption, however, satisfaction may be short lived:

"... the irony is that as persons consume substances to alleviate their distress, they only find a brief and fleeting satisfaction that can only be treated by more consumption... Prescription drugs, in this sense, are often designed to modify behaviors to fit normative patterns of neoliberal agency (e.g., suppress feelings of depression and anxiety to enhance personal focus and competitive/productive behavior, thereby promoting better results in one's job, school, personal life, etc.). [This is] because success, virtue, and happiness in a market society are often associated with material wealth, prestige, and 'coming out on top"' [11, p. 414, 416).

Such observations beg the question of "What's wrong with enhancement?" [see 72]. Specifically, one might ask what is wrong with suppressing anxiety and depression if doing so facilitates the ability and desire to work, or leads people to socialize more, or allows them to better cope with the

\footnotetext{
1 Thus, symptoms could be managed without the invasiveness of existing treatments such as ECT and psychosurgery [68]. While psychotropic drugs played a critical role in facilitating deinstitutionalization during the second half of the twentieth century, the discharge trend resulted primarily from changes in social philosophy and policy [69].
} 
challenges of living in a market society where personal relationships and a sense of community may be lacking? The concern is the suggestion or perception that mental disorders can only be treated - or that mental health can only be achieved - by way of consumption. Also concerning is the de-emphasis of sociocultural dimensions of mental health, and the priority that might be given to interventions which are centered on individuals, based on cost-effectiveness, and implemented without respect to situational considerations such as the etiology of a given disorder and the degree to which diagnostic criteria are met for that disorder. As noted by Midgley [73, p. 2], "The same reductive and atomistic picture now leads many enquirers to propose biochemical solutions to today's social and psychological problems, offering each citizen more and better Prozac rather than asking what made them unhappy in the first place."

\section{PM, G \& E Relationships}

We consider the relationship between personalized medicine (PM), genomics (G) and enhancement (E). Dickenson [1] studied four areas usually considered as PM activities, viz., Retail genetics, Pharmacogenomics, Private umbilical cord blood banking, and Enhancement technologies; and discussed the extent to which each was motivated by (i) threat and contamination, (ii) narcissism and "bowling alone," (iii) corporate interests and political neoliberalism, and (iv) the sacredness of personal choice. She found corporate interests and neoliberal public policies to be the one explanation that works across all four technologies (p. 142). Our choice of what areas to cover and how each was motivated are somewhat different, but retail genetics and private blood banking are just lesser-known variants of what she refers to as PM. Taken all together, we have the ME medicine of Dickenson [1]. We have chosen to distinguish between the (ideal of) PM and the otherwise inspired activities such as direct-to-consumer advertising of genetic assessments, blood banking, etc. and have focused on neoliberalism as the most important motivating factor. We do not see the Hippocratic view of PM as antithetical to Dickenson's WE medicine: Vaccination, widespread and affordable medical care, and clean air and water are part-and-parcel of that which is best for the individual, as well as society at large.

We should also recognize Dickenson's threat as an important factor in the ME activity of assessing genetic risk(s) for disease. Commercial direct-to-consumer genetic testing services are readily available and promise to empower individuals with important information regarding their future health prospects. Rose [41, p. 346] gives some examples.

The genetic risks/predispositions referred to are computed from GWASs, and we have already pointed to a number of the limitations of such studies. If you've got enough money, and you thirst for even more information, you can sequence your entire genome. Problem here is that there is no such thing as the normal, ideal or perfect human genome, so what will you compare it to? Even if one such could be identified, it is guaranteed that yours will not be a perfect match. As put by
Rose [41, p. 348]: “... at the molecular level, no one is normal - everyone has a bunch of little anomalies and it is very hard to predict which of these, in which combinations, and in which circumstances, may impair health."

The following example, taken from Quackenbush [74], is revealing. It is based on James Watson's genomic sequence http://jimwatsonsequence.cshl.edu/ which may have been the first individual genome to be sequenced (Craig Venter sequenced his own genome around the same time, and actually published it before Watson's). Examination of this sequence showed that Watson was homozygous for four highly penetrant, Mendelian recessive disease-causing alleles, but he did not suffer from any of these; pointing to the limited accuracy of exclusively genomic diagnosis/prediction. It is also of interest to note that Watson did not wish to know what his genome said about his apolipoprotein E, or APOE, gene, since a mutation here would (supposedly) point to a predisposition to Alzheimer's disease.

In any event, it is easy to see how the genetic-risk-industry fits into the neoliberal scheme of things. As McGowan and Fishman [75, p. 19] remarked, "The individualization of healthcare and understanding health in terms of genetic risks can be situated within broader political trends towards neoliberal approaches to various sectors of the political economy promoting individual responsibility for one's health, including vigilant self-surveillance to manage genetic health risks." Or, as noted by Sunder Rajan [18, p. 281], "Every individual, because of his or her genomic risk profile, is a potential target for therapeutic intervention. In this calculus, every individual is a patient-in-waiting and, simultaneously, a consumer-in-waiting."

Now, having emphasized that one should not conflate PM with genomics, we can point to the fact that sometimes genomics does influence PM in important ways. Bazell [76] documents one such instance. In the mid-1990s, Genetech developed the breast cancer drug Herceptin, a monoclonal antibody that binds to the human growth factor receptor HER-2, which is involved in regulating cell growth. While initial study results did not show significant effectiveness of the drug in the overall population, subsequent analysis discovered that a subpopulation responded well to treatment. This group $(\approx 25 \%$ of the originally tested women) was characterized by tumors expressing especially high levels of HER-2. The FDA approved the drug for use in such women, and many took this as "proof of concept" of a genetic basis for personalized medicine.

Similarly, Gillick [77] pointed to the success of crizotinib, a targeted chemotherapeutic agent, as a good example of personalized medicine: Lung cancer patients with the so-called ALK (anaplastic lymphoblastic kinase) mutation ${ }^{2}$

2 Chemicals can cause cancer if they damage the genetic material. One mechanism of carcinogenesis is structural damage to the DNA, e.g., substitution of one base pair for another in the DNA (a point mutation), rearrangement of segments between two chromosomes (a translocation), or the joining of pieces of two chromosomes (a fusion). Fusions and translocations proved to be important in causing chronic myelogenous leukemia (CML). This led to the development of a highly effective 
were enrolled in a clinical trial which showed a remarkable response rate to crizotinib of $90 \%$. Minimal side effects were reported. The drug (christened Xalkori) received accelerated FDA approval, and was available for the treatment of the 8,000 lung cancer patients presenting each year harboring the ALK gene. Pfizer set the price for the drug at $\$ 9,600$ per month. The Wall Street Journal thought that the FDA's rapid approval of the drug was a sign that Pfizer's future lay in creating "niche blockbusters," since targeted therapies can be brought to market faster and at lower cost. Gillick suggested that maybe personalized medicine - high-cost, low-volume drugs designed to target specific genetic abnormalities - was the path forward for Pfizer, and perhaps for Pharma more generally.

Still, he recognized that this success story was made possible only by an unlikely convergence of the aims of the different stakeholders involved. The outcome required a combination of things to come together: Patients were eager for an effective drug against lung cancer with minimal toxicity, but were reluctant to enroll in clinical trials. Oncologists were enthusiastic about the new drug, but had a financial incentive favoring intravenous medicines over oral agents. The FDA was under pressure to approve new drugs quickly. The drug manufacturer modified its corporate structure and developed collaborations with academics and international partners, but was pressured by stockholders to maximize short-term profitability. Insurance companies balked at the price of the drug and used tiered pricing to limit their costs.

This suggests that "success" will be realized only when exceptional circumstances allow all stakeholders' interests to achieve some measure simultaneous satisfaction. Importantly, this convergence includes the possibility of targeting a drug to a specific gene mutation in the first place. However, as noted earlier, Miklos [64] warned that the concept here - the idea that cataloging all somatic mutations from primary tumors (the goal of the Human Cancer Genome Project) to serve as the basis for designer drugs to cure most cancers, with success depending upon the assumption that drugs can be targeted to very specific mutated regions of gene products - is open to question. Even should such drug development be possible, he noted, "it is not the primary tumor, but the metastatic spread of a small population of deadly cells...that kills in cancer" [p. 535].

The relationship between (the ME medicine version of) PM and enhancement is best viewed through a neoliberal lens. Enhancement can be seen as the logical extension of the PM industry looking to expand its market. When the deliberate intervention used to enhance is genomic, the G-connection is clear, but $\mathrm{E}$ is often pharmacologically based. In any event, as noted by Callahan and Wasunna [78, p. 30], "The market does

chemotherapeutic agent to treat CML. The drug, imatinib (Gleevec), has a stunning $80 \%$ success rate in treating what was previously a disease with limited treatment options, and it had relatively few side effects. Solid tumors, the most common types of cancer, including breast, lung and colon cancers, were later shown to be associated with the abnormal fusion of two genes. This kind of a gene was then found in a number of patients with cancer of the lung, and it was named the ALK gene, referred to in the text. not just satisfy wants; it also creates them." The so-called infinity model [medical progress should be open-ended, always seeking - whatever the present state of health - even better health, committed to unending new biological knowledge and constant technological innovation, blurring the boundaries between ordinary good health and enhanced human health] of medical aims sets limitless goals and stimulates a constant transformation of wants into needs. Our present health can never be good enough, if only because good health will always be temporary, and medical progress will constantly redefine what good health means." This redefinition was expedited in 1997, when the FDA changed its regulations to allow direct-to-consumer (DTC) advertising. Since then, we have seen an enormous proliferation of DTC advertising, much of this focused on known disorders, offering an appropriate pharmaceutical fix (e.g., Viagra for ED). More and more, however, the disorder itself needed to be medicalized, i.e., presented not as a common character trait, but as a disorder needing treatment. Conrad [79, p. 20] was "troubled that we are moving in the direction of pathologization of everything, where all human differences will be seen as illnesses or disorders."

Conrad [79] showed that such medicalization was being increasingly driven by market forces and the allure of enhancement, new interventions being responses to the "temptations" of biomedical enhancement. Be all that you can be....

\section{WE medicine vs ME Medicine}

Dickenson [1, p. 5] gave examples of WE medicine: "programs like public vaccination, clean water, and screening for tuberculosis - that brought us reduced infant mortality, comparative freedom from contagious disease, and an enhanced life span." She also noted that the VA Hospital System, a widespread and accessible example of publicly funded health care, should be counted in the WE medicine camp. Before pitting this conception of WE medicine against the highly personalized aspects of ME medicine epitomized by genomic approaches and enhancement, we pause to consider an even more basic form of the ME vs. WE question - one that has been with us for a very long time, indeed. Focus on the treatment of an individual patient. Can the clinical trial enterprise be expected to contribute anything to the care of this patient? Armitage [80] thought that for clinical trials to make sense in this context, one must believe that it is possible, by studying groups of patients, to draw conclusions which can be relevant to individual cases, and that this was far from obvious. He noted that the question had been a source of controversy (at least) since the mid- $19^{\text {th }}$ century. He quoted from a famous debate that took place in Paris in 1835:

F. J. Double: "For myself I must say that the more I see of a disease the more does each case appear to me a separate problem ... Individuality is an invariant element in pathology ... Numerical and statistical calculations, open to many sources of fallacy, are in no degree applicable to therapeutics;" and 
Pierre Louis: "A therapeutic agent cannot be employed with any discrimination or probability of success in a given case, unless its general efficacy, in analogous cases, has been previously ascertained; therefore I conceive that without the aid of statistics, nothing like real medical science is possible."

A more up-to-date continuation of this debate (including discussions of which statistical methods may be of most value in this regard) is available in Rothwell [81]. It may be of interest to note that neoliberals were able to capitalize on both sides of this debate: Individuality pointed to the genome and the HGP; variability to the clinical trial industry. This flexibility is the hallmark of the neoliberal marketplace; one needs to be able to follow the money. Much money has been made via development of methods appropriate for the treatment of human diseases. There has been less enthusiasm for the promotion of publicly-run prevention programs. Surely this is a consequence of their limited potential for generating profit; it cannot be because of any defensible doubts about their efficacy.

To cite but two of the many references available to document this efficacy (and the superiority of the WE to the ME approach), consider Rose [42] who pointed out, "...almost all the major advances in human health have come from interventions that have been anything but personal. Clean water, effective sewage systems, regulation of food safety, controls on environmental pollutants, together with population wide programmes of vaccination, maternity services and similar measures are effective precisely because they address the underpinnings of ill health without differentiating individuals, except where they focus on specific groups such as pregnant women and new born babies" (p. 342). He continues "Impersonalization was the route to improved health for all" (p. 343).

And, importantly, he looked beyond efficacy to bolster the WE attitude: "These have not merely been instrumentally effective, they have also embodied a more profound ethic that when it comes to health and illness, each has a responsibility to all, no individual should be held culpable for their illness, or refused treatment because they cannot afford it, or because they have, in someway, brought it upon themselves" (p. 350).

We also point to Hubbard and Wald [82]. Here is a sampling of some of their observations:

"The environment is a tremendously powerful agent in producing alcoholism, but genes are easier to study" (p. 101) ... "High tech experiments drain resources away from the kinds of public health and medical measures that could improve the health of much larger numbers of people (p. 113).. [we] devote huge sums and much effort to eliminating biological causes of illness and death while at the same time accepting as inevitable a steady increase in the death toll from social causes" (p. 117) ... "Norms create deviance (p. 129) ... we need to question the current emphasis on genes as determining our development, health, and behavior. Focusing on genes leads almost inevitably to an assignment of values: these genes are good, those genes are bad. ... Scientists and physicians should not be given the right to assign such labels, but the problem is greater than that. The labels themselves are inherently wrong, no matter who is doing the labeling" ( $p$. 161). "Poverty is the world's deadliest disease. ... Most people in the world do not die because they have 'bad genes,' but for lack of sufficient and nutritious food, clean water, sanitation, and vaccines and other inexpensive medications" (p. 163).

Public health issues (e.g., clean water) are not confined to other, third-world countries. Flint MI is a recent example of our failure to consistently provide basic services to all of our own citizens. Many of us are, everyday, challenged by hazardous workplaces, polluted air, lack of nutritious food, etc. There is no shortage of problems that need to be addressed. Seligman and Csikszentmihalyi [83, p. 5] pointed to the dangers of ignoring these basic human requirements: "... the United States can continue to increase its material wealth while ignoring the human needs of its people... Such a course is likely to lead to increasing selfishness, to alienation between the more and the less fortunate, and eventually to chaos and despair." We believe that, following Juengst [84, p. 256], it is important to “... keep personal problems - like reproductive choices - appropriately personal, and social problems - like workplace safety - securely on the shoulders of society." SOCIAL problems require SOCIAL solutions. We don't need/want a gene therapy solution to global warming.

\section{Conclusions}

We have argued that neoliberalism, with its exclusive reliance on the market, has had deleterious effects on science in general and, in particular, on clinical science and the provision of health care. We focused on personalized medicine (with its focus on individual freedom and choice), genomics (reductionism and genetic determinism), and enhancement (suppliers influence on demand, medicalization/biomedicalization); and considered these in the context of a choice between ME and WE medicine. The case against the exclusive reliance on the market in this context would appear to be an extremely strong one. The argument also can be made more generally to address the structure of our entire health care system; it goes back at least to Arrow [54] who noted that health care is marked by irregular and unpredictable demand, uncertainty of outcomes, inadequate information, and erratic supply conditions. He thought that, under such circumstances, there can be no perfect market, and thus a need for non-market interventions and control. Maher [79] built on these ideas and wrote that the market's normal laws of supply and demand do not apply to medicine. In the traditional economic model, demand is the key; supply is then stimulated to satisfy demand. But in the case of health care, the supplier (often, the doctor) plays a much more active role in determining what consumers (patients) believe they want - or need. The patient is in a uniquely vulnerable position: s/he cannot sample the product beforehand; there is a (real) possibility that the product will do more harm than good; and yet, should it prove useless, $\mathrm{s} /$ he is expected to pay for it. The doctor/patient transaction is based 
on trust, as was emphasized by Arrow [54]. One can continue to insist that the buyer beware, but the part about being aware is informed by the diagnosis given by the doctor.

She also pointed to the VA as a (now) successful health care provider, despite (or maybe because of) the fact that they are not in competition for business. The VA has succeeded where others have failed in large part because it is not competing, and because its patients are not shopping around, moving from one health care plan to another. The VA invested in information technology, and use their database for research, including, importantly, monitoring for safety. Medicare pays at least 50 percent more than the VA pays for half of the top 20 brand-name prescription drugs sold to seniors [85, p. 292]. The Medicare legislation signed by President Bush in 2003 explicitly prohibits Medicare from using its enormous purchasing power to bargain with drug makers [85, p. 262]. So much for market freedom ... Some readers will counter anything good we may have to say about the VA with a vague recollection that the VA suffers from a chronic "waiting-in-line" problem. This can be relatively easily fixed. It is more difficult for the uninsured 45 million Americans to find a line to wait in.

Two other ways in which health care is mismatched to an unfettered market can be noted. First, in many other industries technology saves money; in the world of health care, increasingly sophisticated technology usually leads to ever more expensive treatments. And finally, while competition can buffer costs under certain circumstances, competition can just as easily drive up costs: you cannot compete for customers by offering fewer services or amenities in a market such as health care, where people want better not worse care.

Callahan and Wasunna [78, p. 262] note that, "The market has no internal guidance mechanisms for grappling with the nature of health, the meaning of the goals of medicine, and the place of health in human life. But there can be no good medicine unless those most basic of issues are confronted and debated ... It was Adam Smith's genius to acknowledge that the market lacked a moral core, and that it was the underlying society and culture that had to compensate for that lack."

We now need to concede that the deleterious effects identified above were the result(s) of a complete, uncompromising acceptance of all aspects of the neoliberal ideology under any and all circumstances. There is no compelling reason why it need be complete.

Exclusive reliance on the market can lead to bad outcomes. As an illustration, we consider Esposito and Perez's [11, p. 13] summation of the mental health situation in the United States, "After decades of neoliberal policies and a psychopharmacological revolution that began converting those suffering from mental distress into consumers, a large segment of the U.S. population does not appear to be any saner, happier, less anxious, or less distressed". Indeed, despite tremendous strides in the understanding and treatment of mental illness, and increased spending on mental health care including psychotropic medications, more people are experiencing mental health issues now than in the past. Roughly one-quarter of Americans who seek mental health care receive treatment that is not therapeutic or not indicated for their condition. Mental, behavioral, and neurological disorders are the leading cause of disability in the U.S. [11; 86-90].

By and large, the mental health field has witnessed over the course of more than 50 years that approaches which reflect neoliberal ideology and/or rely exclusively on psychopharmacological intervention have not served to advance the prevention and management of mental illness [see 83]. By the same token, reductionist approaches that pathologize human behavior as a reflection of market objectives can lead to bad outcomes. This does not mean that the invisible hand cannot produce good outcomes under some (other) conditions. Context is important. The paradox is this: The aforementioned approaches have been constructive - perhaps even instrumental - in the formation of several schools of thought (e.g., humanism; counseling, health, and positive psychology) that arose as reactions against the reductionist/pathology perspective suggesting a shift away from neoliberal ideology [83, 91-94]. A common thread among these schools is the philosophy of systematically building competency, which, by way of evidence-based practices such as community treatment and psychoeducation, as well as recovery models that focus on outcomes that patients believe are most critical (e.g., acceptable housing, meaningful work, and quality-of-life), has consistently been shown to account for improved mental health functioning - an outcome that many would consider good $(53 ; 83 ; 95-99]$. Thus, it could be argued that aspects of neoliberalism encompassed by the reductionist/pathology perspective had a circuitous hand in promoting mental health.

We want to be careful not to leave the impression that one needs to be either all-in or all-out of the market; or that one needs to adopt either the reductionist or the holistic approach to science, writ large. Or that it's big science vs little science, one or the other. All patents/enhancements are bad ...That WE medicine should be adopted instead of ME medicine irrespective of context. We should not be forced to make a choice - one or the other - between ME medicine and WE medicine. Horses for courses...

A thoughtful discussion of the market's role (if any) in medicine was given by Callahan and Wasunna [78]. They considered the place of market theory and practice in medicine and health care, asking can we/should we deploy market practices to further health goals? They thought it important to realize that market tools can be applied to parts of the health care system without being all-encompassing. Piecemeal application depends on what they call the instrumentalist viewpoint - the market is a set of tools that might be used to enhance the efficiency of various aspects of health care. This is contrasted with a political viewpoint wherein the market is seen as the key to the spread and success of democracy, prosperity, and human freedom; more than an instrumental tool. A particular political viewpoint considered (p. 41) is the "fundamentalist" which is "prone to be antigovernment, at least in the sense of wanting a minimal government role in health care; ...maximum consumer choice and do not hesitate 
to think of patients as consumers; ... the health market generates technological innovation, which has both medical and economic value; and ... freedom is clearly more important than equity." Here the connection to neoliberalism is clear. The result of their enquiry was that the fundamentalist political viewpoint would not result in an equitable health care system, but that there might be some life left in the instrumental view: "The market is not the way to go as a general panacea for health care, even if it works well in other sectors of society. But possibly it can contribute something. We want to leave that door open, looking carefully before entering" [78, p. 274].

Callahan $[100$, p. 20] reiterated these points in a follow-up discussion in which he was explicit about the edifice to which the door was left ajar: "I believe that a government-run or government-regulated healthcare system mandating universal healthcare is the best kind of system - but that there is some room for carefully considered market practices within, or aiming at, such care."

We believe that this stance - that one might cautiously consider some role for the market in some healthcare context is a reasonable one, perfectly compatible with horses for courses. That Daniel Callahan might be capable of this insight would have come as a surprise to Tom Koch who called out Callahan for providing the ammunition required for governments bent on restricting health budgets without having to consider system reform [101, p. 69]. In particular, he thought that arguments given by Callahan [102, 103] helped fuel the politics of Ronald Reagan: "Cutting back federal spending on social programs and deregulating the private sector would, in what came to be called Reaganomics, promote business health; cutting costs in socially mandated medical programs would, somehow, sooner or later build a better future" (p. 71).

Koch questioned Callahan's view that economic limits required the sacrifice of some for the benefit of the future many: "... to say resources are not infinite is not to say they are necessarily scarce and must be rationed. We may choose to limit service to the elderly, the immigrants, or the poor on the basis of scarcity, but what we're really saying is that we'd rather spend our resources on other things, or people" (p. 74). He thought that Callahan's ethic was focused on the economic: "Medicine's goal, as he [Callahan] defined it, was or should be the maintenance of economically valuable workers" (p. 67). This focus diverted attention from questions about how the presumed scarcity came about - Might we ask about how to avoid scarcity questions in the first place, rather than who should be forced to bear the brunt of those that exist? As stated by Koch [101, p. 70]: "Instead of a discussion of the ethics of national health coverage, or the potential inefficiencies of the healthcare system, the focus became the insupportable cost of care for the superannuated and by extension all those who were judged unproductive."

Callahan found the traditional Hippocratic view of medicine to be in need of modernization. Advances in medical science and technology had caused health care costs to increase at unsustainable rates, and he thought that limiting access to needed care would be necessary for us to continue to be able to afford to pay the bill. Koch [101, p. 149] countered: "If there was a challenge to the traditional ethics of medicine at mid-century it lay not in the complexities of new science and technology but in the impatience of researchers and their employers who were less interested in patient care than in cost control and product development."

Koch also thought that the bioethics profession as a whole, not just Callahan, was complicit in modernizing the ethics of medical care so as to accommodate business interests at the expense of those in need. Bioethics" "broader concept of benefit" substituted the perceived needs of the economy, and the lucrative knowledge industry, for the care of the patient as a primary good. Indeed, one of the profession's landmark achievements, The Belmont Report, is quite transparent about this [104]. Koch [101, p. 125] thus criticized the Belmont Report's distinction between patient and [research] subject: "In separating the medical patient from the research subject, they opened the door for a bioethical perspective in which the needs of the patient-cum-subject would ever be secondary to those of the knowledge industry and its potential production of future benefit" (p. 125). An interesting case report of the effects neoliberalism has had on the ethical norms of medicine is given by Mayes et al [105].

We return to horses for courses and the supposed choice that needs to be made between reductionism and holism. The crux of the problem is that the 'conflict' between the two is not universal: They will be compared in context - whatever conflict exists will center on whether a reductionist or holistic approach is appropriate in the context of studying a specific phenomenon. We don't have to ask whether reductionism can work well in certain situations; it has done so. Many times. So often, in fact, that Medewar and Medewar [106, p. 227] claimed that, "Reductive analysis is the most successful research stratagem ever devised: it has been the making of science and technology." Similarly, there will be times when a holistic approach will be all but required, as when the very attempt at reduction destroys the phenomenon we wish to study. That the holistic/reductionistic dichotomy is in general a false one, can be seen from the words of Lewontin [35, p. 15] who rejects both strict reductionism and strict holism: "The problem is to construct a third view, one that sees the entire world neither as an indissoluble whole nor with the equally incorrect, bur currently dominant, view that at every level the world is made up of bits and pieces that can be isolated and that have properties that can be studied in isolation." One such view was called dialectical materialism by Lewontin and Levins [107, p. 10], a view that "emphasizes wholeness, connectedness, historical contingency, the integration of levels of analysis, and the dynamic nature of 'things' as snapshots of processes."

We also believe the "Big Science/Big Data vs Little Science" dichotomy is a false one. The either-or view is just too simplistic. Context is important. This view is not a new one, but the "we or them" mentality arises from time-to-time, especially when funding is seen to be limited. Esparza and Yamada [108] pointed to two of the first proponents of "big 
science," Alvin Weinberg [109] and Albert Sabin [110] noting that while they were encouraging of large, collaborative research efforts to solve certain important, complex problems, neither saw any contradiction between the Big Science approach to biomedicine and the more traditional ways of doing science. Both pleaded for more Big Science and for more Little Science. They concluded, "These two approaches to biomedical science are not in contradiction, but are complementary and mutually stimulating" (p. 701). Hood and Rowen [62, p. 3] added, "Big science and smaller-scope individual-investigator-oriented science are powerfully complementary, in that the former generates resources that are foundational for all researchers while the latter adds detailed experimental clarification of specific questions, and analytical depth and detail to the data produced by big science."

GWASs are big science, taking a "hypothesis-free" stance. Hypothesis-free and hypothesis- driven research paradigms are, also, sometimes placed on an either/or footing where one is being asked to vote for one or the other. Again, we plead false dichotomy, as stated by Kell and Oliver [111, p. 99]: "data- and technology-driven programmes are not alternatives to hypothesis-led studies in scientific knowledge discovery but are complimentary and iterative partners with them." When evaluating the GWAS approach, some deplore the fishing expedition flavor of the research and point to the 'missing heritability problem' as proof of its futility. However, the "missing heritability problem" is indeed a problem only if the purpose of the study is to account for large chunks of heritability. The "problem" might simply be a misrepresentation of the objective of GWASs. If the aim of GWAS is to detect loci that are associated with common traits, GWASs have been largely successful [44]. Horses for courses....

One final thought. If one were to "boil down" the claims of this essay to a single thread (admittedly a bald, reductionist maneuver) it would be that the neoliberal ideal of the "commodification of everything" is too ambitious and, in particular, needs to be avoided in the areas of science and health care delivery.

\section{References}

[1] Dickenson D (2013) ME Medicine vs. WE Medicine: Reclaiming biotechnology for the common good. New York: Columbia University Press.

[2] Harvey D (2005) A Brief History of Neoliberalism. New York: Oxford University Press.

[3] Brown W (2015) Undoing the Demos: Neoliberalism's stealth revolution. New York: Zone Books.

[4] Mirowski P (2014) Never Let A Serious Crisis Go To Waste: How neoliberalism survived the financial meltdown. New York: Verso.

[5] Michaels D (2008) Doubt is their Product: How industry's assault on science threatens your health. Oxford University Press.
[6] Resnik DB (2007) The Price of Truth: How money affects the norms of science. Oxford University Press.

[7] Ginsburg GS and Willard HF (2009) Genomic and personalized medicine: foundations and applications. Translational Research 154(6): 277-287.

[8] Giroux HA (2014) Neoliberalism's War on Higher Education. Chicago IL: Haymarket Books.

[9] Olssen M and Peters M (2005) Neoliberalism, higher education and the knowledge economy: from the free market to knowledge capitalism. Journal of Education Policy 20(3): 313-345.

[10] Fisher JA (2009) Medical Research for Hire: The political economy of pharmaceutical clinical trials. New Brunswick NJ: Rutgers University Press.

[11] Esposito L and Perez FM (2014) Neoliberalism and the commodification of mental health. Humanity \& Society 38(4): 414-442.

[12] Rissmiller DJ and Rissmiller JH (2006) Evolution of the antipsychiatry movement into mental health consumerism. Psychiatric Services 57(6): 863-866.

[13] Everett B (2000) A fragile revolution: Consumers and psychiatric survivors confront the power of the mental health system. Waterloo, Ontario: Wilfrid Laurier University Press.

[14] Lewontin R, Rose S and Kamin LJ (1984) Not in our Genes: Biology, Ideology, and Human Nature. New York: Pantheon.

[15] Nelkin D and Lindee MS (2004) The DNA Mystique. Ann Arbor MI: University of Michigan Press.

[16] Midgley M (2010) The Solitary Self: Darwin and the selfish gene. New York: Routledge.

[17] Ridley M (1999) Genome: The autobiography of a species in 23 chapters. New York: Harper Perennial.

[18] Rajan KS (2006) Biocapital: The constitution of postgenomic life. Durham NC: Duke University Press.

[19] Rose N (2007) The Politics of Life Itself: Biomedicine, power, and subjectivity in the twenty-first century. Princeton NJ: Princeton University Press.

[20] Chadwick R (2014) The ethics of personalized medicine: A philosopher's perspective. Personalized Medicine 11(1): 5-6.

[21] Fleck LM (2010) Personalized medicine's ragged edge. Hastings Center Report 40(5): 16-18.

[22] Personalized Medicine Coalition (2014) The Case for Personalized Medicine. Fourth edition. Available at: www.personalizedmedicinecoalition.org (Accessed January 30, 2017).

[23] Hamburg MA and Collins FS (2010) The path to personalized medicine. New England Journal of Medicine 363(4): 301-304.

[24] Kowalski CJ and Mrdjenovich AJ (2013) Patient preference trials: Why and when they will sometimes be preferred. Perspectives in Biology and Medicine 56(1): 18-35.

[25] Gamma A (2014) The role of genetic information in personalized medicine. Perspectives in Biology and Medicine 56(4): 485-512. 
[26] Gilbert W (1992) A vision of the grail. In: D. J. Kevles, and L. Hood, eds. The Code of Codes: Scientific and social issues in the human genome project. Cambridge MA: Harvard University Press, pp. 83-97.

[27] Carey N (2012) The Epigenetic Revolution. How modern biology is rewriting our understanding of genetics, disease, and inheritance. New Kork: Columbia University Press.

[28] Keller EF (1995) Refiguring Life: Metaphors of twentieth-century biology. New York: Columbia University Press.

[29] Panofsky A (2015) From behavior genetics to postgenomics. In: Richardson SS and Stevens $\mathrm{H}$ (eds) Postgenomics: Perspectives on Biology after the Genome. Durham NC: Duke University Press: pp. 150-73.

[30] Keller EF (2015) The postgenomic genome. In: Richardson SS and Stevens H (eds) Postgenomics: Perspectives on Biology after the Genome. Durham NC: Duke University Press: pp. $9-31$.

[31] Stevens H and Richardson SS (2015) Beyond the genome. In: Richardson SS and Stevens $\mathrm{H}$ (eds) Postgenomics: Perspectives on Biology after the Genome. Durham NC: Duke University Press: pp. 1-8.

[32] Keller EF (2010) The Mirage of a Space between Nature and Nurture. Durham NC: Duke University Press.

[33] Graeber D (2015) The Utopia of Rules: On technology, stupidity. Brooklyn NY: Melville House.

[34] Kevles DJ and Hood L (eds) (1992) The Code of Codes: Scientific and social issues in the human genome project. Cambridge MA: Harvard University Press.

[35] Lewontin R (1991) Biology as Ideology. New York: Harper Collins.

[36] Tauber AJ and Sarkar S (1992) The Human Genome Project: Has blind reductionism gone too far? Perspectives in Biology and Medicine 35(2): 220-235.

[37] Strohman RC (1993) Ancient genomes, wise bodies, unhealthy people: Limits of a genetic paradigm in biology and medicine. Perspectives in Biology and Medicine 37(1): 112-145.

[38] Hood L (1992) Biology and medicine in the twenty-first century. In: Kevles DJ and Hood L (eds) The Code of Codes: Scientific and social issues in the human genome project. Cambridge MA: Harvard University Press: pp. 136-163.

[39] Fortun M (2005) For an ethics of promising, or: a few kind words for James Watson. New Genetics and Society 24(2): 157-173.

[40] Fortun M (2008) Promising Genomics: Iceland and deCODE Genetics in a world of speculation. Berkeley CA: University of California Press.

[41] Rose N (2013) Personalized medicine: Promises, problems and perils of a new paradigm for healthcare. Procedia - Social and Behavioral Sciences 77: 341-352.

[42] Frazer KA, Ballinger DG, Cox DR et al. (2007) A second generation human haplotype map of over 3.1 million SNPs. Nature 449(7164): 851-861.

[43] Rose N (2008) Race, risk and medicine in the age of 'Your Own Personal Genome.' BioSocieties 3(4): 423-439.
[44] Visscher PM, Brown MA, McCarthy MI et al. (2012) Five years of GWAS discovery. American Journal of Human Genetics 90(1): 7-24.

[45] Stranger BE, Stahl EA and Raj T (2011) Progress and promise of genome-wide association studies for human complex trait genetics. Genetics 187(2): 367-383.

[46] Lango AH, Estrada K, Lettre G et al. (2010) Hundreds of variants clustered in genomic loci and biological pathways affect human height. Nature 467(7317): 832-838.

[47] Steele EJ (2014) Reflections on ancestral haplotypes: Medical genomics, evolution, and human individuality. Perspectives in Biology and Medicine 57(2): 179-197.

[48] Patel CJ, Bhattacharaya J and Butte AL (2010) An environment-wide association study (EWAS) on Type 2 diabetes mellitus. PLoS One 5: 1-10. e10746.

[49] Khoury MJ and Wacholder S (2008) From Genome-Wide association studies to Gene-Environment-Wide interaction studies -- Challenges and opportunities. American Journal of Epidemiology 169(2): 227-230.

[50] Gigerenzer G (1991) From tools to theories: A heuristic of discovery on cognitive psychology. Psychological Review 98(2): 254-67.

[51] Lewontin R (2001) It Ain't Necessarily So: The dream of the human genome and other illusions. Second edition. New York: The New York Review of Books.

[52] Pettigrew M and Roberts H (2003) Evidence, hierarchies, and typologies: horses for courses. Journal of Epidemiology and Community Health 57(7): 527-529.

[53] Kowalski CJ and Mrdjenovich AJ (2014) Comparative effectiveness research. Perspectives in Biology and Medicine 57(2): 224-248

[54] Arrow KJ (1963) Uncertainty and the welfare economics of medical care. The American Economic Review 53(5): 941-973.

[55] Nerlich B and Hellsten L (2009) Beyond the human genome: microbes, metaphors and what it means to be human in an interconnected post-genomic world. New Genetics and Society 28(1): 19-36.

[56] Schneider CW and Winslow R (2014) The human microbiome, ecological ontology, and the challenges of community. Perspectives in Biology and Medicine 57(2): 208-23.

[57] Blaser M, Bork P, Fraser C, Knight R and Wang J (2013) The microbiome explored: recent insights and future challenges. Nature Reviews Microbiology 11: 213-17.

[58] Shostak S and Moinester M (2015) The missing piece of the puzzle? Measuring the environment in the postgenomic moment. In: Richardson SS and Stevens H (eds) Postgenomics: Perspectives on Biology after the Genome. Durham NC: Duke University Press: pp 192-209.

[59] Parrington J (2015) The Deeper Genome: Why there is more to the human genome than meets the eye. Oxford University Press.

[60] Graur DY, Zheng Y, Price N et al. (2013) On the immortality of television sets: 'function' in the human genome according to the evolution-free gospel of ENCODE. Genome Biology and Evolution 5(3): 578-590. 
[61] Green ED, Watson JD and Collins FS (2015) Human Genome Project: Twenty-five years of big biology. Nature Comment 30 September 2015.

[62] Hood L and Rowen L (2013) The Human Genome Project: big science transforms biology and medicine. Genome Medicine 5(9): 79.

[63] Tripp S and Greuber M (2011) Economic Output of the Human Genome Project. Columbus: Battelle Memorial Institute.

[64] Miklos GL (2005) The Human Cancer Genome Project - one more misstep in the war on cancer. Nature Biotechnology 23: 535-537.

[65] Leaf C (2004) Why we're losing the war on cancer (and how to win it). Fortune 149(6): 76-97.

[66] Brown PO and Botstein D (1999) Exploring the new world of the genome with DNA microarrays. Nature Genetics Supplement 21: 33-37.

[67] Buchanan A (2011a) Beyond humanity? Oxford: Oxford University Press.

[68] Healy D (2002) The Creation of Psychopharmacology. Cambridge MA: Harvard University Press.

[69] Gronfein W (1985) Psychotropic drugs and the origins of deinstitutionalization. Social Problems 32(5): 437-454.

[70] Moncrieff J (2006) Psychiatric drug promotion and the politics of neoliberalism. British Journal of Psychiatry 188(4): 301-302.

[71] Hamilton C (2003) Growth Fetish. Crow's Nest, NSW, Australia: Allen \& Unwin.

[72] Temkin LS (2013) What's wrong with enhancement? Journal of Medical Ethics 39(12): 729-731.

[73] Midgley M (2004) The Myths We Live By. New York: Routledge.

[74] Quackenbush J (2011) The Human Genome. Watertown MA: Charlesbridge Publishing.

[75] McGowan ML and Fishman JR (2008) Using lessons learned from BRCA testing and marketing: What lies ahead for whole genome scanning services. American Journal of Bioethics 8(6): $18-20$.

[76] Bazell R (1998) Her-2: The making of Herceptin, a revolutionary treatment for breast cancer. New York: Random House.

[77] Gillick MR (2014) Targeted chemotherapy, the medical ecosystem, and the future of American health care. Perspectives in Biology and Medicine 57(2): 268-284.

[78] Callahan D and Wasunna AA (2006) Medicine and the Market: Equity v. choice. Baltimore MD: Johns Hopkins University Press.

[79] Conrad P (2006) Up, down, and sideways. Society 43(6): 19-20.

[80] Armitage P (1984) Controversies and achievements in clinical trials. Controlled Clinical Trials 5(1): 67-72.

[81] Rothwell PM (ed) (2007) Treating Individuals: From randomized trials to personalized medicine. Edinburgh:
Elsevier.

[82] Hubbard R and Wald E (1999) Exploding the Gene Myth: How genetic information is produced and manipulated by scientists, physicians, employers, insurance companies, educators, and law enforcers. Boston MA: Beacon Press.

[83] Seligman MEP and Csikszentmihalyi M (2000) Positive psychology: An introduction. American Psychologist 55(1): 5-14.

[84] Juengst ET (2004) Concepts of disease after the human genome project. In: Caplan AL, McCartney JJ and Sisti DA (eds) Health, Disease and Illness. Washington DC: Georgetown University Press: pp. 243-62.

[85] Mahar M (2006) Money-Driven Medicine: The real reason health care costs so much. New York: HarperCollins.

[86] American Psychiatric Association (2013) Diagnostic and statistical manual of mental disorders (5th ed). Washington DC: American Psychiatric Association.

[87] National Institute of Mental Health (2013) Statistics. Available at: http://www.nimh.nih.

gov/health/publications/the-numbers-count-mental-disorders-i n-america/index.shtml (Accessed January 30, 2017).

[88] Seligman MEP (1994) What You Can Change \& What You Can't. New York: Knopf.

[89] Susser ES, Schwartz S, Morabia A et al. (2006) Psychiatric epidemiology: Searching for the causes of mental disorders. New York: Oxford University Press.

[90] Aanstoos C, Serlin I and Greening T (2000) A history of Division 32. In D. Dewsbury (ed) Unification through division: Histories of the Divisions of the American Psychological Association. Washington DC: American Psychological Association.

[91] McLeroy KR, Bibeau D, Steckler A et al. (1988) An ecological perspective on health promotion programs. Health Education Quarterly 15(4): 351-377.

[92] Mrdjenovich AJ and Moore BA (2004) The professional identity of counseling psychologists in health care settings. Counselling Psychology Quarterly 17(1): 69-79.

[93] Sallis JF and Owen N (2002) Ecological models of health behavior. In: Glanz K, Rimer BK and Lewis FM (eds) Health Behavior and Health Education: Theory, research, and practice. San Francisco CA: Jossey Bass.

[94] American Psychological Association Presidential Task Force (2006) Evidence-based practice in psychology. American Psychologist 61(4): 271-285.

[95] Kupfer DJ, Kuhl EA and Regier DA (2013) DSM-5-The future arrived. Journal of the American Medical Association 309(16): 1691-1692.

[96] Anthony W, Rogers ES and Farkas M (2003) Research on evidence-based practices: Future directions in an era of recovery. Community Mental Health Journal 39(2): 101-114.

[97] Deegan PE (1997) Recovery and empowerment for people with psychiatric disabilities. Social Work in Health Care 25(3): 11-24.

[98] Frese FJ, Stanley J, Kress K et al. (2001) Integrating evidence-based practices and the recovery model. Psychiatric Services 52(11): 1462-1468. 
[99] Ralph RO and Corrigan PW (2005) Recovery in mental illness: Broadening our understanding of wellness. Boston MA: Boston University Center for Psychiatric Rehabilitation.

[100] Callahan D (2009) Medicine and the market. In: DG Arnold (ed) Ethics and the Business of Biomedicine, Cambridge University Press.

[101] Koch T (2012) Thieves of Virtue: When Bioethics stole Medicine. Cambridge MA: MIT Press.

[102] Callahan D (1987) Setting Limits: Medical Goals in an Aging Society. New York: Simon and Schuster.

[103] Callahan D (1990) What Kind of Life? The Limits of Medical Progress. Washington DC: Georgetown University Press.

[104] Kowalski CJ, Hutchinson RJ and Mrdjenovich AJ (2017) The ethics of clinical care and the ethics of clinical research: Yin and yang. Journal of Medicine and Philosophy 42(1): 7-32.

[105] Mayes CB, Blakely I, Kerridge P et al. (2016) On the fragility of medical virtue in a neoliberal context: the case of commercial conflicts of interest in reproductive medicine. Theoretical Medicine and Bioethics 37(1): 97-111.
[106] Medawar PB and Medawar JS (1983) Aristotle to Zoos: A philosophical dictionary of biology. Cambridge MA: Harvard University Press.

[107] Lewontin R and Levins R (2007) Biology Under the Influence: Dialectical essays on ecology, agriculture, and health. New York: Monthly Review Press.

[108] Esparza J and Yamada T (2007) The discovery value of "Big Science." Journal of Experimental Medicine 204(4): 701-704.

[109] Weinberg AM (1967) Reflections on Big Science. Cambridge MA: MIT Press.

[110] Sabin AB (1967) Collaboration for accelerating progress in medical research. Science 156(3782): 1568-1571.

[111] Kell DB and Oliver SG (2003) Here is the evidence, now what is the hypothesis? The complementary roles of inductive and hypothesis-driven science in the post-genomic era. BioEssays 26(1): 99-105. 